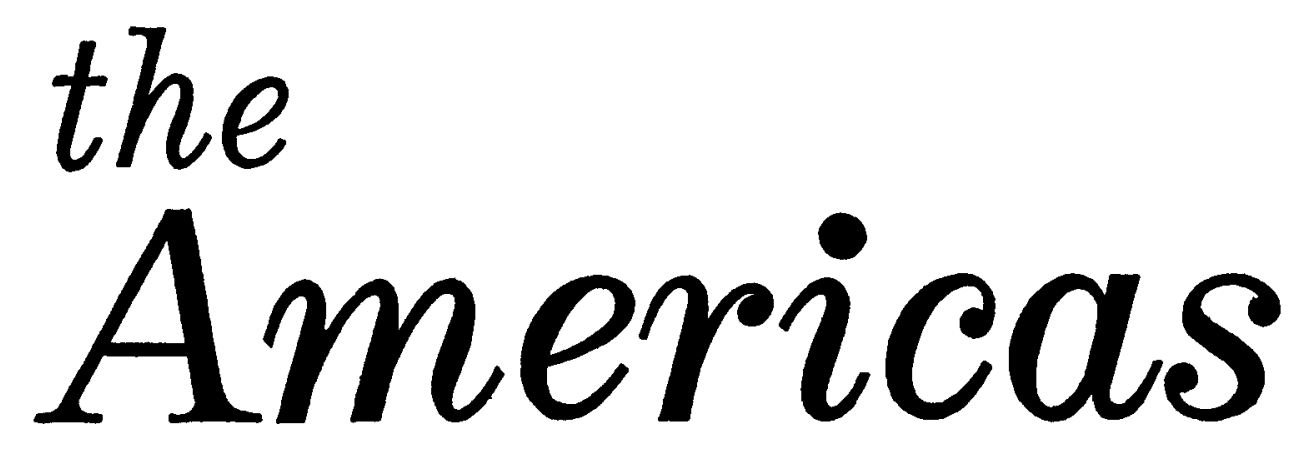

A QUARTERLY REVIEW OF INTER-AMERICAN CULTURAL HISTORY

\title{
VOLUME XXXIII
}

\section{JULY, 1976 THROUGH APRIL, 1977}

Published Quarterly by the Academy of American franciscan History Washington, D.C. 


\section{ARTICLES}

The Deadly Selva: Paraguay's Northern Indian Frontier Jobn Hoyt Williams 1

The Quiet Experiment In American Diplomacy: An Interpretative Essay On United States Aid To

The Bolivian Revolution ............ G. Earl Sanders

Governor Carranza And The Revolution In Coahuila William H. Beezley 50

Enrico Martínez Of New Spain ........ Valerie L. Mathes 62

Patterns Of Spanish Emigration To The Indies, 1579-1600

Peter Boyd-Bowman 78

The Barco Concession In Colombian-American Relations, 1926-1932 Stephen J. Randall 96

The Radicalization Of The Uruguayan Student Movement Mark J. Van Aken 109

Colombian Reactions To The Independence Of Panama, 1903-1904 Josepb L. Arbena 130

Reflections On Revolution In America, 1776-1976 Max Savelle 185

Santiago, Chile, 1541-1581: A Case Study

Of Urban Stagnation

Jobn B. Fichandler and Thomas F. O'Brien, Jr. 205

The Wealth Of The Jesuits In Mexico, 1670-1767

James D. Riley 226

Juan Esteban De Ubilla And The Flota Of 1715

Lowell W. Newton 267

The Harassed Exile: Genfral Cipriano Castro, 1908-1927

William M. Sullivan 282

Carranza And The Decision To Revolt, 1913: A Problem

IN Historical INTERPRETATION Mark T. Gilderhus 298

Economic Nationalism And Tax Reform In Late

Nineteenth Century Chile

William F. Sater 311 
Spanish Parishes In Colonial New Granada:

Their Role In Town Building ON

The Spanish-American Frontier

Gary W. Graff 336

Guayaquil Through Independence: Urban Development

In A Colonial System .. Micbael Conniff 385

Narcisco Durán And The Secularization Of

The California Missions

Michael C. Neri 411

The Construction Of The Interoceanic Railroad

of Guatemala

Delmer G. Ross 430

Sources In Lima For The Study Of The Colonial

Consulado of Peru

Lawrence A. Clayton

457

The Catholic Historian In Nineteenth Century Chile

Allen Woll 470

Education In New Granada: Lorenzo María Lleras

And The Colegio Del Espirítu Santo, 1846-1853

Robert H. Davis

490

The Black Ragamuffins: Radical Hypocrisy In Nineteenth

Century Southern Brazil

Spencer L. Leitman 504

Federal-State Relations During The Porfiriato: The Case OF SONORA, 1879-1884

Donald M. Coerver 567

O Exemplo: Afro-Brazilian Protest In Pôrto Alegre

Jobn F. Bratzel and

Daniel M. Masterson

585

Inter-American Trade In The Early 1870s-A State.

Department Survey

David M. Pletcher 593

Price Regulation In Hispanic California

Robert A. Arcbibald

613

Benito Juárez Versus The Díaz Brothers: Politics In Oaxaca, 1867-1871 Frank S. Falcone 630

The Indigenista Novel And The Mexican Revolution

Donald L. Schmidt

652

NOTES AND REVIEWS

InTER-American Notes

$149,352,519,661$

Book Reviews

$164,365,537,678$ 


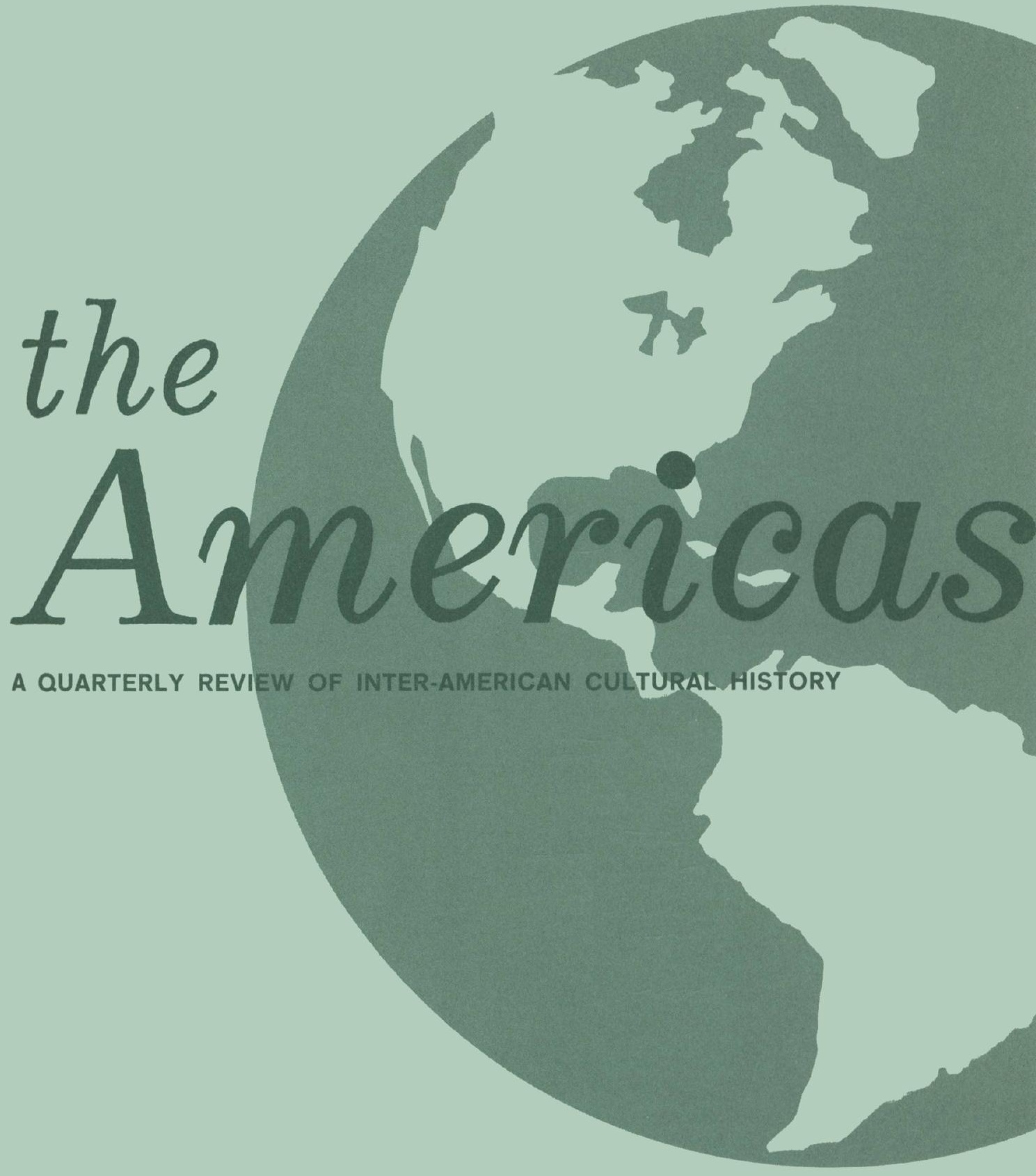

published by the

ACADEMY OF AMERICAN FRANCISCAN HISTORY

Washington, D.C. 
EDITORIAL STAFF

Editor

ANTONINE S. TIBEsar, O.F.M.

Assistant Editors

Francisco Morales, O.F.M.

James D. Riley

Richard W. Gronet

Carol Ann Prebce

Secretary

Rosemarie AnNe LunN

\section{AREA EDITORS}

RoBin B. ANDERSON

University of California-Davis

Joseph L. Arbena

Clemson University

William H. BeEzley

North Carolina State University

JUNE E. HAHNER

State University of New York at Albany

Michael T. Hamerly

Archivo Historico Del Guayas

Kenneth J. Grieb

University of Wisconsin-Oshkosh
JOHN M. HART

University of Houston

JAIME ROdRIGUEZ O.

University of California, Irvine

Thomas SchoONOVER

University of Southwestern Louisiana

\author{
William L. Sherman \\ University of Nebraska \\ John Hoyt Williams \\ Indiana State University
}

\section{SENIOR EDITORS}

\author{
Dauril Alden \\ University of Washington \\ Lino G. Canedo, O.F.M. \\ Washington, D. C. \\ Donald C. Cutter \\ University of New Mexico \\ Maynard Geiger, O.F.M. \\ Santa Barbara, California \\ Richard E. GreenleaF \\ Tulane University \\ George P. Hammond \\ University of California \\ Mathias C. Kiemen \\ Washington, D. C.
}

John Tate Lanning

Duke University

Javier Malagón-Barceló

Organization of American States

Michael C. Meyer

The University of Arizona

John L. Phelan

University of Wisconsin

FREDRICK B. PIKE

Notre Dame University

Philip Wayne Powell

University of California at Santa Barbara

France V. Scholes

University of New Mexico 


\section{the}

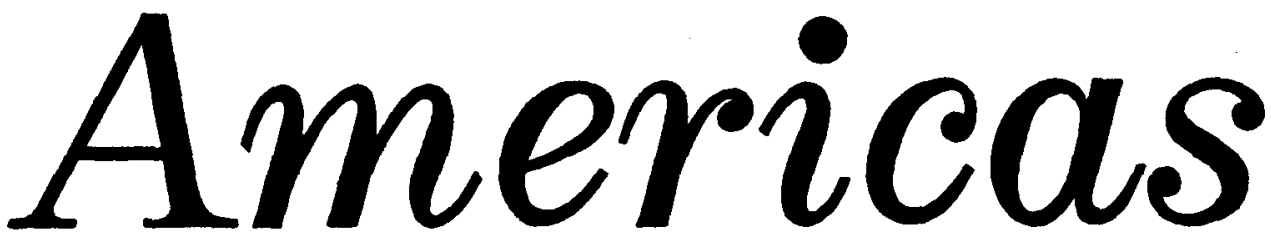

A QUARTERLY REVIEW OF INTER-AMERICAN CULTURAL HISTORY

The Deadly Selva: Paraguay's Northern Indian Frontier

The Quiet Experiment In American Diplomacy: An Interpretative Essay On United States Aid To The Bolivian RevOLUTION

G. Earl Sanders

Governor Carranza And The Revolution In Coahuila

William H. Beezley

Enrico Martínez Of New Spain

Valerie L. Mathes

Patterns Of Spanish Emigration To The Indies, 1579-1600

The Barco Concession In Colombian-American Relations, 1926-1932 Stephen J. Randall

The Radicalization Of The Uruguayan Student Movement Mark J.Van Aken 109

Colombian Reactions To The Independence Of Panama, 19031904

INTER-AMERICAN Notes

Book Reviews

(Listed on following page)

Copyright, 1976

ACademy of American Franciscan History

In citing, please use TAm 


\section{BOOK REVIEWS}

Nigel Davies: The Aztecs: a bistory.

Stephen A. Colston

Luis G. Lumbreras: The Peoples and Cultures of Ancient Peru.

Michael E. MOSELEY

Luis Martin: The Kingdom of the Sun. A Short History of Peru. JEFFrey KLAIBER

Javier Malagón y Barceló: Código Negro Carolino.

RAYFoRd W. LOGAN

Neill Macaulay: The Prestes Column Revolution in Brazil. JoHN D. WIRTH

Verena Martínez-Alier: Marriage, Class and Colour in Nineteenth-Century Cuba.

FranKLIN W. KNIGHT

Jean-Pierre Blancpain: Les Allemands au Cbili (1816-1945).

EugENe H. Korth

Arnaldo Córdova: La ideología de la Revolución Mexicana: La formación del nuevo régimen. La formación del poder politico en México. David C. Bailey

Colin M. MacLachlan: Criminal Justice in Eighteentb Century Mexico. A Study of the Tribunal of the Acordada Ruth Pike

Charles H. Harris, III: $A$ Mexican Family Empire: The Latifundio of the Sánchez Navarros, 1765-1867

James D. Riley

Jan Bazant: Cinco Haciendas Mexicanas. Tres siglos de vida rural en San Luis Potosí (1600-1910)

T. G. POWELL

Peggy K. Liss: Mexico Under Spain, 1521-1556. Society and the

Origins of Nationality. UrSUla Lamb

Celsus Kelly, O.F.M., (Ed.): Austrialia Franciscana. Volumes V and VI.

ANDRE GSCHAEDLER

Francisco Perez i Ferrer: Notes Historiques: Aportació a la bistoria de Soller.

Norman Holub

Published by

THE ACADEMY OF AMERICAN FRANCISCAN HISTORY

Editor: ANTONINE S. TIBESAR, O.F.M.

Editorial and Publication offices: Box 34440, Washington, D. C., 20034. Printed by Capital City Press, INc., Montpelier, Vermont 05602. All correspondence and books for review should be sent to the Editor at the editorial office. THE AMERICAS is published quarterly (January, April, July and October). Annual subscription: Pan American countries, direct subscription $\$ 5.00$; United States and other countries, $\$ 10.00$. Current single numbers $\$ 2.50$ each; back numbers $\$ 4.00$ each. Opinions expressed are the responsibility of the contributors. Second-class postage paid at Rockville, Maryland and other post offices. 